\title{
Aloe vera and Virgin Coconut Oil (VCO) accelerate healing process in domestic cat (Felis domesticus) suffering from scabies
}

\author{
Tridiganita Intan Solikhah $^{1}$, Gahastanira Permata Solikhah ${ }^{2}{ }^{\circledR}$ and Raden Joko Kuncoroningrat \\ Susilo $^{3}$ (D) \\ ${ }^{1}$ Division of Veterinary Clinic, Faculty of Veterinary Medicine, ${ }^{2}$ Cahaya Petshop, Veterinarian, Mojokerto, Indonesia \\ ${ }^{3}$ Doctoral Program in Mathematics and Natural Sciences, College of Science and Technology, University Airlangga, \\ Surabaya, Indonesia
}

\begin{tabular}{l} 
Article information \\
\hline Article history: \\
Received August 4, 2020 \\
Accepted August 30,2020 \\
Available online October 1, 2021 \\
\hline Keywords: \\
Aloe vera gel \\
Medicine \\
Virgin coconut oil \\
Cat \\
Scabies \\
\hline Correspondence: \\
T.I. Solikhah \\
tridiganita@ fkh.unair.ac.id
\end{tabular}

\begin{abstract}
The objective of this study is to know the formula in making Aloe vera gel cream with VCO to create a scabies medicine and know which treatment gives the fastest healing effect of scabies in domestic cats in Mojokerto. The first step is to extract Aloe vera by infundation method, phytochemical identification test, making Aloe vera cream, testing the washing power of the cream, and testing the effect of Aloe vera gel cream on 32 cats suffering from scabies in Mojokerto, then the skin of cats suffering from scabies scraped and observed under a microscope to observe the ectoparasites that cause scabies in cats. Cats were divided into 4 treatments namely A, B, C and D. The results of this study indicated skin scrapping on 32 cats scabies in Mojokerto, exist 26 cats that were positive for Notoedres cati, 2 cats positive for Sarcoptes scabiei and 4 cats are negative. Formulas used for the manufacture of creams included stearic acid, triethanolamine, adeps lanae, paraffin liquid, VCO, nipagin, nipasol, aquades, and Aloe vera. The results of the three groups of cream formulas B, C, D caused a significant cure in cats suffering from scabies compared to control group A.
\end{abstract}

DOI: $10.33899 /$ ijvs.2020.127884.1539, (CAuthors, 2021, College of Veterinary Medicine, University of Mosul.

This is an open access article under the CC BY 4.0 license (http://creativecommons.org/licenses/by/4.0/).

\section{Introduction}

Scabies in cats is a highly contagious disease that can be transmitted from animals to humans, and vice versa that caused by a tiny mite named Notoedres cati and Sarcoptes scabiei (1). Scabies burrow in the skin and cause a crusty dermatose, primarily in sparsely hairy areas, including the head, neck, axillae, groin and tail (2). Ordinary scabies present at burrowing site as papular or vesicular lesions, as well as a generalized allergic rash accompanied by intense itching (3). Therefore, scabies in cats must be treated to prevent thickening and skin folding accompanied by the appearance of crust. Indonesia as a mega-biodiversity country, many plant resources can be used to treat scabies based on its bioactivity content. The progress of modern science that is increasingly rapid and sophisticated today should not rule out natural medicine (4-6). In addition, there is still a lack of knowledge and information about various types of plants that could be used as natural medicines for certain treatments that can be developed into a formulation (7-9). One alternative that can be utilized is by making a combination of extracts made from Aloe vera and $\mathrm{VCO}$, Aloe vera plants and $\mathrm{VCO}$ waste can be found in the environment around the house and many are sold in traditional markets and modern markets. So it is very easy to get. Aloe vera plant belonging to the family Liliaceae, has some considerable potential as a raw material for natural medicine. The opportunities for medical plants are increasing, as well as the tendency of people to switch to natural ingredients. Natural materials also have the opportunity to become a large trading commodity. Aloe vera plant originating from Africa has more than 360 species. Species of the commercial genus Aloe include Aloe barbadansis, Aloe perryl and Aloe ferox. 
Aloe barbadansis or often called Aloe vera has the highest potential as a pharmaceutical raw material (10).

In the case of scabies that attack animals, there is literature sourced from $(6,11,12)$, that says Aloe vera effective for healing scabies. Based on this, I would like to know the effect of Aloe vera if added with other ingredients, namely

VCO.VCO is described as an oil resulting from the fresh an $\mathrm{d}$ mature coconut kernel (Cocos nucifera L.) by mechanical and natural means, either by heat or without alteration or $\mathrm{tr}$ ansformation of the coconut oil.

VCO has many advantages, including the health benefits of the vitamins and antioxidants retained, the lauric acid component antimicrobial and antiviral activity and its easy digestibility from medium chain fatty acids (MCFA) $(13,14)$. VCO has a range of benefits and good medical properties, such as anti-inflammatory, analgesic, and antipyretic. The content of VCO is one of the unsaturated chain fatty acids that can block free radicals and maintain the immune system. This makes VCO useful for preventing and treating various health problems. VCO also has a natural oil texture, free of pesticides, and other contaminants, its composition facilitates absorption and gives a soft and smooth texture to the skin (15).

Based on the background above and the results of previous studies, researcher is interested in conducting this research as reference material or information, related to the effect of giving extract cream containing Aloe vera extract and VCO to domestic cats (Felis domesticus) that suffer from scabies. Cream is chosen because it is one of the topical dosage forms generally used for local therapy (16).

The cream dosage form is preferred by the public because it is easy to clean and easily spread. Cream preparations are chosen because they have the advantage of being attractive, simple in their manufacture, easy to use, good absorption and giving a cool feeling to the skin (17).

\section{Materials and methods}

\section{Sampling}

In this study the object used was a cat whose surface had little or no hair, scab and thickening of the skin. The cats used were 32 domestic cats that suffer from scabies in Mojokerto, Indonesia, if the cat has scabies, it will be continued with treatment. Cats were divided into 4 treatments namely A, B, C, and D.

\section{Identification of ectoparasites}

To identify ectoparasites it was done by skin scrapping on 32 cats suffering from scabies. Skin scrapping method was done by scraping the scabies infested skin. The scrapings were clarified with a $10 \% \mathrm{KOH}$ solution, placed on an object glass, then covered with a cover glass and examined under a microscope at magnification of 40 times.

\section{Aloe vera gel with infundation method}

Aloe vera plant was obtained from Jalan Bratang, Surabaya City. Aloe vera sample was obtained by cutting the base of $5 \mathrm{~cm}$ and then cutting it into small pieces and peeling the skin. The sample was then washed with running water until the sap disappeared, then weighed until a $500 \mathrm{~g}$ Aloe vera was obtained. Aloe vera gel was blended immediately and the result in the form of a crude extract was filtered and heated to a temperature of $70{ }^{\circ} \mathrm{C}$ for 10 minutes, then obtained as much as $\pm 100 \mathrm{~mL}$ of Aloe vera extract

\section{Tannin and phenol examination}

A total of $5 \mathrm{~mL}$ Aloe vera gel was put into a test tube, then added 5 drops of $10 \% \mathrm{NaCl}$, then the solution was divided into 2 parts into different test tubes. The first test tube was used as a control. The second test tube was added 3 drops of $\mathrm{FeCl}_{3}$, then left for a while. The change of color to black-green color, indicating the presence of phenol and tannin compounds contained in the sample (18).

\section{Saponin examination}

A total of $5 \mathrm{~mL}$ of Aloe vera gel, put into a test tube, shaken vigorously for 10 seconds. If stable froth is formed, it indicates the presence of saponins (19).

\section{Steroid examination}

As much as $5 \mathrm{~mL}$ of Aloe vera gel was dropped with Liebermann Burchard reagent consisting of 3 drops of anhydrous acetic acid and 1 drop of concentrated sulfuric acid, if it appears red, then it indicates the presence of terpenoid compounds, if formed a green or blue color then it indicates the presence of steroid compounds.

\section{Making Aloe vera cream}

The cream was made with a composition based on the results of previous studies, namely on the basis of a cream that can cure scabies within 7 weeks (Table 1).

Table 1: Cream base formula

\begin{tabular}{lccccc}
\hline Material & Unit & $\mathrm{A}$ & $\mathrm{B}$ & $\mathrm{C}$ & $\mathrm{D}$ \\
\hline Stearic Acid & $\mathrm{g}$ & 14.5 & 14.5 & 14.5 & 14.5 \\
Trietanolamin & $\mathrm{mL}$ & 1.5 & 1.5 & 1.5 & 1.5 \\
Adeps lanea & $\mathrm{g}$ & 3 & 3 & 3 & 3 \\
Paraffin & $\mathrm{mL}$ & 5 & 5 & 5 & 5 \\
VCO & $\mathrm{mL}$ & 0 & 20 & 0 & 20 \\
Nipagin & $\mathrm{g}$ & 0.1 & 0.1 & 0.1 & 0.1 \\
Nipasol & $\mathrm{g}$ & 0.05 & 0.05 & 0.05 & 0.05 \\
Aquades & $\mathrm{mL}$ & 100 & 100 & 100 & 100 \\
\hline
\end{tabular}

The manufacture of Aloe vera cream was done by considering all the necessary ingredients. The ingredients contained in the formula were separated into two of groups 
namely the oil phase and the water phase. The oil phase, namely stearic acid, paraffin liquid, adeps lanae, is transferred in a porcelain cup, heated on a hot plate at a temperature of $70^{\circ} \mathrm{C}$ to melt.

The water phase, Triethanolamine and distilled water, was heated on a hot plate at $70^{\circ} \mathrm{C}$ until it melts. The water phase was slowly entered into the oil phase then add nipasol and nipagin with constant stirring until a homogeneous cream mass is obtained. $\mathrm{C}$

ream was made by: pouring Aloe vera gel and VCO into a porcelain dish containing $100 \mathrm{~g}$ of cream, crushed slowly until homogeneous (Table 2).

Table 2: Cream formulations

\begin{tabular}{lcccc}
\hline Material & A & B & C & D \\
\hline Aloe vera gel & - & - & $10 \%$ & $15 \%$ \\
VCO & - & $20 \mathrm{~mL}$ & - & $20 \mathrm{~mL}$ \\
Cream Base & $100 \mathrm{~g}$ & $100 \mathrm{~g}$ & $100 \mathrm{~g}$ & $100 \mathrm{~g}$ \\
\hline
\end{tabular}

\section{Cream washing power}

Cream-washed power check. $1 \mathrm{~g}$ cream was applied to the palm of the hand and then washed with a volume of water while rinsing hands. Water was passed from the burette slowly, visually observe the presence or absence of cream left in the palm of the hand, note the volume of water used (20).

\section{Testing the effect of Aloe vera gel cream}

Testing the effect of the cream on cats suffering from scabies. Cats were divided into 4 treatments namely A, B, C and $\mathrm{D}$. A treatment as a control. The $\mathrm{B}$ treatment was applied with $20 \mathrm{~mL} \mathrm{VCO}$ with $100 \mathrm{~g}$ of formula cream, C treatment was applied with a mixture of $10 \%$ Aloe vera gel with $100 \mathrm{~g}$ of formula cream, D treatment was applied with a mixture of $15 \%$ Aloe vera gel and $20 \mathrm{~mL}$ of VCO with $100 \mathrm{~g}$ of formula cream. Each treatment was applied once a day to the skin with scabies and then carried out observations every day to see the effects that occur. The parameter observed was the loss of scabies.

\section{Statistical analysis}

Analyzing data carried out by a one-way analysis of variance (ANOVA) accompanied by various reference checks by Tukey. The results were considered statistically significant if $\mathrm{P}<0.05$.

\section{Results}

\section{Physical examination results}

Physical and clinical examination results of inspection and palpation show skin abnormalities in the form of hyperkeratosis of the ear and the presence of wounds. Cats show symptoms of pruritus by continuing to scratch the ear area.

\section{Skin scrapping examination results}

Examination of skin scrapings is done because of clinical symptoms such as hyperkeratosis of the skin on the ear and the cat often scratches the ear. The results of the diagnostic test of skin scrapping method on 32 cats that were naturally infested with scabies in Mojokerto, there were 26 cats that were positive for $S$ cati, 2 cats positive for Sarcoptes scabiei, and 4 cats are negative. Cats were given cream treatment for 7 weeks of treatment. Physical examination was carried out at weekly intervals of up to 7 weeks after treatment. On 4th week, pruritus began to disappear. There was a clinically significant improvement after 7 weeks of treatment. Seven weeks after treatment, skin scrapings were examined and ectoparasites were found to be negative.

\section{Phytochemical identification test results of Aloe vera gel with infundation method}

Phytochemical identification test results showed that Aloe vera gel using the infundation method contained three active compounds namely phenol, tannin, and saponin (Table 3).

Table 3: The phytochemical identification test results of Aloe vera gel using the infundation method

\begin{tabular}{lcccc}
\hline \multirow{2}{*}{ Method } & \multicolumn{4}{c}{ Phytocomponents } \\
\cline { 2 - 5 } & Phenol & Tannin & Steroid & Saponin \\
\hline Infundation & + & + & - & + \\
\hline +: indicates the content of the substance being analyzed. -: \\
does not indicate the content of the substance being \\
analyzed.
\end{tabular}

\section{Results of making Aloe vera gel cream and virgin coconut oil}

The results of making scabies cream obtained by Aloe vera gel cream using the infundation method, where the cream used as vanishing cream base. Based on visual observations, the cream is white. Checking the washing power of cream in B and D 1 gram can be washed well with $14 \mathrm{~mL}$ distilled water while in formulas A and $\mathrm{C} 1$ gram can be washed with $17 \mathrm{~mL}$ distilled water. Washability is related to the type of cream $\mathrm{m} / \mathrm{a}$ that will be more easily washed compared to the type of $\mathrm{a} / \mathrm{m}$ (21). Organoleptic examination of Aloe vera gel and VCO cream formula did not show any change in shape, color and odor. The homogeneity examination of Aloe vera cream showed that all preparations were homogeneous and evenly dispersed, this examination was carried out every week for 7 weeks of observation.

\section{Test results of the effects of Aloe vera cream and virgin coconut oil}

The results of testing the effects of Aloe vera cream and VCO on scabies cats were characterized by skin damage in the epidermis and which has been found positive for Notoedres cati and Sarcoptes scabiei using a microscope. Changes in the average diameter of the scabies were 
measured until the scabies were declared cured for each treatment. The results of the three groups of cream formulas B, C, D caused a significant cure in cats suffering from scabies compared to control group A, the best scabies drugs were $\mathrm{B}$ and $\mathrm{D}$ extract containing VCO in the cream. In D cream, there were changes in diameter of scabies to 0 on week 5 , whereas B cream can cure scabies on week $6, \mathrm{C}$ cream can cure on week 7 and A cream cannot cure scabies. Theoretically these results proved that creams containing VCO can accelerate healing of scabies within 5-6 weeks. While, creams that contain Aloe vera can cure scabies within 7 weeks (Figure 1).

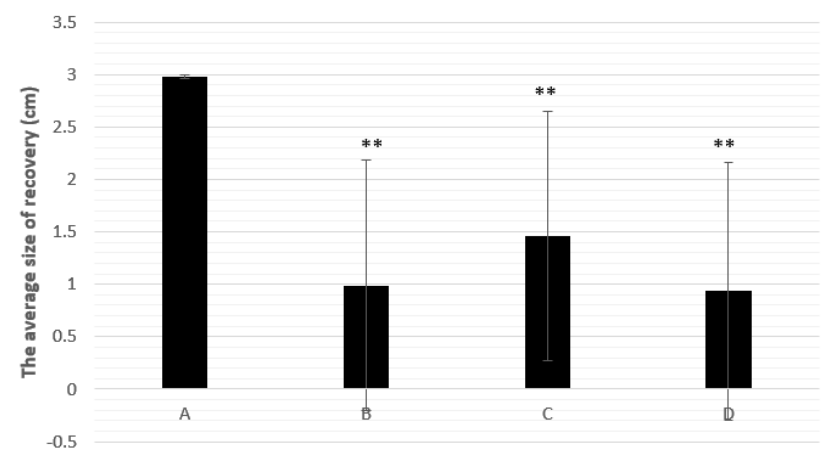

Figure 1: The results of healing scabies in cat.

\section{Discussion}

Scabies is a skin disease caused by one or several species of mites, which are spread through direct contact with animals that are infested or environments that have been contaminated by these mites with different prevalence and pathogenicity. This disease can affect large animals and small animals (21-22).

Animals that are attacked will experience itchiness that causes a decrease in body condition, causing economic losses, and if it occurs in pets such as dogs and cats clinically can look disgusting and zoonotic (infectious to humans).

Mite's life cycle is female mites will create tunnels in the skin (23), then lay eggs, after 3-8 days the eggs will hatch into larvae, then the larvae will be nymph, then undergo a subsequent skin change into adult mites.

Transmission can occur from one animal to another susceptible animal through an infestation of larval, nymph, or adult stages.

The incubation period varies from 2-6 weeks, depending on the number of infesting mites, location and host susceptibility. In general, the stage of development includes eggs, larvae, nymphs ( 1 or 2 ), and adults.

The diagnosis of scabies is by microscopic examination of skin scrapings or skin scabs (usually the boundary between the skin that changes and normal), to direct the diagnosis, the distribution of lesions observed include frequent infestation of the ear, causing itching so that it will be scratched, rubbed or bitten so that it looks skin inflammation, and very contagious (contagious).

Examination of skin scrapings observed under a microscope found Notoedres cati and Sarcoptes scabiei mites. Notoedres cati was found in 26 cats and Sarcoptes scabiei was found in 2 cats suffering from scabies in Mojokerto. Cats show intense crust formation, hyperkeratosis, alopecia and pruritus.

Observation in cats for 7 weeks showed changes in the reduction in thickness and scab on skin, dry wounds, and the start of connective tissue repair to form new skin structures.

Wound healing is a normal process in response to injury to skin tissue and is a complex and dynamic biological process, where the factors involved are regeneration and repair of tissue damage to be replaced by healthy new tissue (24).

The infundation method is the most common method used to obtain the content of active compounds that are soluble in water then the extracts obtained were analyzed by phytochemical identification tests to ensure the presence or absence of active compounds attracted during the gelling process.

The selection of this method is based on several reasons, namely this technique uses laboratory equipment and materials that are quite simple and easily obtained, only require a small amount of sample, the time required is relatively short, and provides fairly accurate examination results.

However, this method is only limited to determining the content of active compounds qualitatively, thus the amount of content contained in the gelling results is unknown.

From Table 3 it was found that Aloe vera gel using the infundation method proved to contain active compounds in the form of phenols, tannins, and saponins. This was due to the water-soluble nature of phenols, tannins, and saponins, while the sterol test obtained negative results because sterols are compounds that cannot dissolve in water but able to dissolve in alcohol.

Tannins function as an astringent that can cause narrowing of the pores of the skin, harden the skin and act as an antimicrobial and antifungal so as to prevent secondary infection in the wound. Tannins are polyphenols with strong antioxidant activity that can protect against damage to free radicals caused by UV exposure and reduce the risk of skin cancer (25). Tannins are able to reduce the production of $\mathrm{H}_{2} \mathrm{O}_{2}$, inhibits the induction of ornitine decarboxylase and stimulates DNA synthesis in the epidermis (26).

Phenol has the ability as an antiseptic to protect the skin so that there is no infection in the skin. The effect of phenol is toxic to scabies mites. The role of bacteriostatic originating from formaldehyde and phenol compounds works in an effort to prevent and control microbial, making the secondary infection accompanying scabies also disappear. Phenols can also prevent damage due to oxidation reactions that occur in cosmetics and are useful for tissue regeneration (27). 
Saponin is a surface active compound produced from a group of steroids or triterpenes that bind to sugar, this compound has a beneficial biological effect in nature of hypocholesterolemic and anticarcinogenic and able to enhance the immune system. Saponins inhibit growth or kill microbes by interacting with the sterol membrane. The main effect of saponins on bacteria is the release of proteins and enzymes from the cells (28).

Aloe vera gel cream using a cream base containing VCO was able to provide effectiveness faster than other formulas. VCO was used to accelerate the healing of scabies because it is an oil that contains saturated chain fatty acids that support healing and repair of body tissues (29). According to research conducted by (12) not only relieve the symptoms of sunburn, Aloe vera gel can also reduce itching due to scabies. A 2009 study published in Phythotheraphy research found evidence of the effectiveness of this material for scabies (12). From the results of the study, it was found that Aloe vera gel is as effective as benzyl benzoate which is commonly prescribed to treat scabies. In fact, research has found that no side effects occur when a person is treated with this one ingredient.

\section{Conclusion}

From this study, we can conclude that a cream containing Aloe vera and Virgin Coconut Oil (VCO) can significantly cure scabies.

\section{Competing interests}

The authors declare that they have no competing interests.

\section{References}

1. Goldust M, Rezaee E, Raghifar R, Naghavi-Behzad M. Ivermectin vs lindane in the treatment of scabies. Ann Parasitol. 2013;59(1):37-41. DOI: $10.3109 / 09546634.2012 .723122$

2. Hardy JI, Fox MT, Loeffler A, Sinclair G. Feline Sarcoptic Mange in the UK: A Case Report. 2012. DOI: 10.1136/vr.101001

3. Mounsey KE, McCarthy JS, Walton SF. Scratching the itch: New tools to advance understanding of scabies. Trends Parasitol. 2013;29(1):3542. DOI: $10.1016 / j . p t .2012 .09 .006$

4. Khairullah AR, Solikhah TI, Ansori ANM, et al. A review of an important medicinal plant : Alpinia galanga (L.) willd. Syst Rev Pharm. 2020;11(10):387-395.

5. Khairullah AR, Solikhah TI, Ansori ANM, et al. Medicinal importance of Kaempferia galanga L. (Zingiberaceae): A comprehensive review. J Herbmed Pharmacol. 2021;10(3):281-288.

6. Ansori ANM, Kharisma VD, Solikhah TI. Medicinal properties of Muntingia calabura L.: A Review. Res J Pharm Technol. 2021;14(8):4505-4508. DOI: 10.52711/0974-360X.2021.00784

7. Pratasik MCM, Yamlean PVY, Wiyono WI. Formulasi dan uji stabilitas fisik sediaan krim ekstrak etanol daun sesewamua (Clerodendron squamatum Vahl.). 2019;8(2):257-263. DOI: 10.35799/pha.8.2019.29289

8. Solikhah TI, Setiawan B, Ismukada DR. Antidiabetic activity of papaya leaf extract (Carica Papaya L.) isolated with maceration method in alloxan-induces diabetic mice. Syst Rev Pharm. 2020;11(9):774-778.

9. Khairullah AR, Solikhah TI, Ansori ANM, et al. Review on the
Pharmacological and Health Aspects of Apium Graveolens or Celery: An Update. Syst Rev Pharm. 2021;12(1):606-612.

10. Bashir A, Saeed B, Mujahid TY, Jehan N. Comparative study of antimicrobial activities of Aloe vera extracts and antibiotics against isolates from skin infections. African J Biotechnol. 2011;10(19):38353840. DOI: $10.5897 / \mathrm{AJB} 07.572$

11. Sindhu ZD, Ullah S, Abbas RZ, Iqbal Z, Hameed M. Inventory of ethno-veterinary practices used for the control of parasitic infections in District Jhang, Pakistan. Int J Agric Biol. 2012;14(6):922-928.

12. Oyelami OA, Onayemi A, Oyedeji OA, Adeyemi LA. Preliminary study of effectiveness of Aloe vera in scabies treatment. Phyther Res. 2009;23:1482-1484. DOI: 10.1002/ptr.2614

13. Mansor TST, Che Man YB, Shuhaimi M, Abdul Afiq MJ, Ku Nurul FKM. Physicochemical properties of virgin coconut oil extracted from different processing methods. Int Food Res J. 2012;19(3):837-845.

14. Solikhah TI, Solikhah GP. The effect of Virgin coconut oil waste in the ration against broiler chicken growth (Gallus Sp). Ecol Environ Conserv. 2019;25:S55-S60.

15. Abujazia MA, Muhammad N, Shuid AN, Soelaiman IN. The effects of virgin coconut oil on bone oxidative status in ovariectomised rat. Evidence-based Complement Altern Med. 2012;2012:1-7. DOI: $10.1155 / 2012 / 525079$

16. Majid NS, Citraningtyas G. Formulasi dan uji efektivitas krim antibakteri ekstrak daun nangka (Artocarpus heterophyllus Lam.) terhadap bakteri Staphylococcus aureus. 2019;8(2):219-227. DOI: 10.35799/pha.8.2019.29257

17. Yenti R, Afrianti R, Afriani L. Formulasi krim ekstrak etanol daun kirinyuh (Euphatorium odoratum. L) untuk penyembuhan luka. Maj Kesehat PharmaMedika. 2011;3(1):227-230.

18. Mailoa MN, Mahendradatta M, Laga A, Djide N. Tannin extract of guava leaves (Psidium guajava $\mathrm{L}$.) variation with concentration organic solvents. Int J Sci Technol Res. 2013;2(9):106-110.

19. Dahanayake JM, Perera PK, Galappatty P, Perera HDSM, Arawwawala LDAM. Comparative phytochemical analysis and antioxidant activities of tamalakyadi decoction with its modified dosage forms. Evidencebased Complement Altern Med. 2019;2019:1-9. DOI: $10.1155 / 2019 / 6037137$

20. Kumalasari E, Mardiah A, Sari AK. Formulasi sediaan krim ekstrak daun bawang dayak (Eleutherine palmifolia (L) Merr) dengan basis krim tipe $\mathrm{A} / \mathrm{M}$ dan basis krim tipe M/A. J Farm Indones AFAMEDIS. 2020;1(1):23-33

21. Oktavia MD, Ayu SK, Halim A. Pengaruh basis krim terhadap penetrasi Kloramfenikol. Farm Higea. 2012;4(1):42-49.

22. Cho BK. Reemerging skin disease caused by arthropods I: scabies. J Korean Med Assoc / Taehan Uisa Hyophoe Chi. 2011;54(5):511-520. DOI: $10.5124 / \mathrm{jkma} .2011 .54 .5 .511$

23. Gürel MS, Erdemir AVT, Tekin B. A Case Report of Real-Time in vivo Demonstration of Sarcoptes scabiei. Turkish J Parasitol. 2017;41:229232. DOI: $10.5152 / \mathrm{tpd} .2017 .5408$

24. Miladiyah I, Prabowo BR. Ethanolic extract of Anredera cordifolia (Ten.) Steenis leaves improved wound healing in guinea pigs. Universa Med. 2012;31(1):4-11. DOI: 10.1805/UnivMed.2012.v31.4-11

25. Jo HJ, Chung KH, Yoon JA, Lee KJ, Song BC, An JH. Radical scavenging activities of tannin extracted from amaranth (Amaranthus caudatus L.). J Microbiol Biotechnol. 2015;25(6):795-802. DOI: 10.4014/jmb.1409.09088

26. Purwaningsih S, Salamah E, Adnin MN. Photoprotective effect of sunscreen cream with addition of carrageenan and black mangrove fruit (Rhizopora mucronata Lamk.). Ilmu dan Teknol Kelaut Trop. 2015;7(1):1-14. doi:10.1007/s00299-018-2282-9. DOI: 10.1007/s00299-018-2282-9

27. Duan X, O’Donnell K, Sun H, Wang Y, Wang S. Sulfur and nitrogen Co-doped graphene for metal-free catalytic oxidation reactions. Smalljournal. 2015;11(25):3036-3044. DOI: 10.1002/smll.201403715

28. Warganegara E, Restina D. Getah Jarak (Jatropha curcas L.) sebagai Penghambat Pertumbuhan Bakteri Streptococcus mutans pada Karies Gigi. Med J Lampung Univ. 2016;5(3):1-6.

29. Viste GB, Silvestre RC, Tabije NB, Silvestre JQ. Efficacy of Virgin Coconut (Cocos nucifera) oilsoap against mange in dogs. Int Sci Res J. 2013;5(2):227-241. 
بطريقة الغمر، واختبار تحديد المكونات النباتية الكيميائية، ثم تصنيع كريم الصبار ، واجر اء اختبار قوة غسل الكريم، ومن ثم اختبار التبار كريم هلام

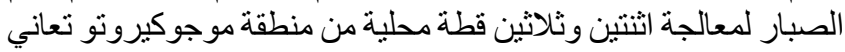

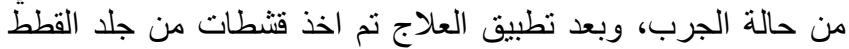

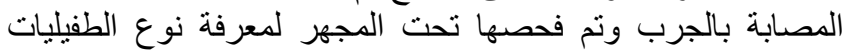
الخارجية المسببة للجرب في تلك القطط. تم تقسيم القطط الى ألى أربعة

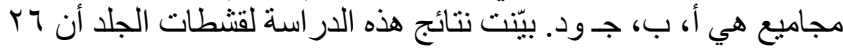

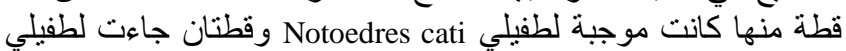
Notoedres cati

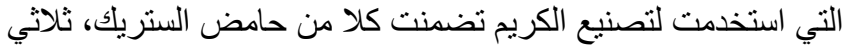

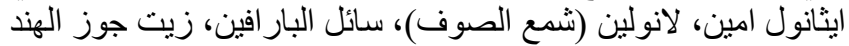

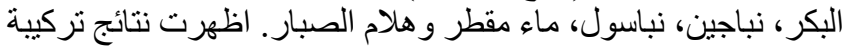

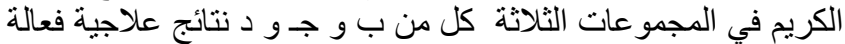
و معنوية في علاج حالات الجرب بالمقارنة مع مجمو عة السيطرة أ.

\section{هلام الصبار وزيت جوز الهزد البكر وتاثير هما المسرع لعملية الالتئسام في القطط المحلية (Felis domesticus)

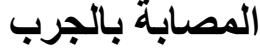

\section{تريديكانتا إنتان سوليكاه'، كهاستاناريا سوليكاهُ و رادن جوكو كونكورونينكرات سوسيلو سيكان}

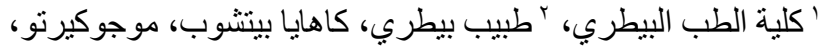

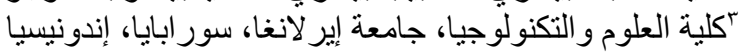

$$
\begin{aligned}
& \text { ان الغرض من هذه الدراسة هو معرفة تركيبة لصنع كريم هلامي }
\end{aligned}
$$

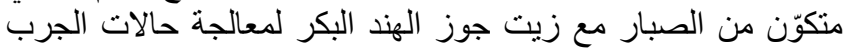

